\title{
Dairy Cattle Husbandry Practices and Coping Strategies Against Feed Scarcity in Buno Bedele Zone, South Western Ethiopia
}

\author{
Amanuel Bekuma*, Yohanis Addisu \\ Department of Animal Science, Mettu University, Bedele, Ethiopia \\ Email address: \\ amanuelbekuma11@gmail.com (A. Bekuma) \\ ${ }^{*}$ Corresponding author
}

\section{To cite this article:}

Amanuel Bekuma, Yohanis Addisu. Dairy Cattle Husbandry Practices and Coping Strategies Against Feed Scarcity in Buno Bedele Zone, South Western Ethiopia. Science Research. Vol. 9, No. 2, 2021, pp. 21-26. doi: 10.11648/j.sr.20210902.11

Received: February 17, 2021; Accepted: March 29, 2021; Published: April 23, 2021

\begin{abstract}
The study was aimed with to study dairy cattle husbandry practices and coping strategies against feed scarcity in selected districts of Buno Bedele zone, south western Ethiopia. Both purposive and simple random sampling techniques were used to select kebeles and household respondents. For this study, a total of 384 households were used for an interview. Of the total land size occupied by the respondents, higher proportions (5.07 \pm 2.739$)$ were used for communal grazing land followed by land for cereal production $(2.86 \pm 1.495)$; land for coffee $(1.02 \pm 0.965)$ and land for forest land $(0.85 \pm 0.585)$. As the current result indicated majority (42.9\%) of the households were used communal natural pasture as the main feed source, especially during the wet seasons; and road and river side and aftermath grazing $(15.6 \%)$ were also used as feed resource in the study areas. As compared with tethering during wet grazing $(27.8 \%)$, free grazing $(72.12 \%)$ remains the major and dominant feeding system practiced in the study areas. In the study area grain leftover $(27.6 \%)$ were the major supplementary feeds followed by and mill by products (20.3\%) and house wastes, atela and common salt (19.01\%). River (72.13\%), pip water (22.1\%) and deep water $(5.73 \%)$ were the major drinking water in the study areas. Of the total respondents, majority $(72.65 \%)$ of them housed their dairy cows in open kraal followed by adjoin house (22.92\%). As the current study indicated Trypanosomiasis, Mastitis, Foot and mouth disease (FMD) were the commonly occurred diseases of dairy cattle reported by $23.44 \%, 19.8 \%$ and $17.7 \%$, respectively. Changing feed recourse based on availability and cost $(26.3 \%)$, rent land and grows fodder $(23.7 \%)$ and reducing herd size $(21.4 \%)$ were the available copying strategy against feed scarcity, respectively in the study areas.
\end{abstract}

Keywords: Buno Bedele, Copying Strategy, Dairy Cattle, Feed Scarcity, Husbandry

\section{Introduction}

Ethiopia is one of the countries of Sub-Saharan Africa with the largest livestock population, and is ranked $5^{\text {th }}$ on the world. The total cattle population of the country is estimated to be 61.59 million CSA [1], of which 6,690,662 were dairy cows. The country holds large potential for dairy development due to its large livestock population; the favorable climate for improved crossbred cows, the relatively disease-free environment, better market opportunity and proximity to international markets.

Dairy sector is a major contributor to economic development, especially among the developing countries, both driving economic growth and benefiting from it. As an engine of growth, it provides increased income, employment, food and foreign exchange earnings as well as better nutrition. As income increases with economic development, the share of animal products in total food budget increases faster than that of cereals. This occurs because of the relatively high-income elasticity of demand for animal products Dayanandan [2].

Despite the existing high potential for dairy development, the performance of the Ethiopian dairy sub-sector has been lagging far behind that of the neighboring countries with comparable agro-ecological conditions Lemma et al. [3]; at 19 liters per annum annual milk consumption is extremely low and well below the world average of 105 liters and the African average of about 41 liters CSA [4]. This is due to the fact that there are lots of genetic and non-genetic factors that hamper the dairy sector development in the country. The 
others milk quality and quantity depends on dairy feeds [5].

With cattle population of 24,479,280 Oromia National Regional state stands first in Ethiopia, Buno Bedele Zone has 437,688 dairy cattle used for milking purpose CSA [1]. Hence, Buno Bedele zone is very well suited for dairy cattle production because the area is endowed with such enormous cattle resources and climatic situations conducive to dairy cattle production. There is also high demand for dairy and dairy products and there is no a cultural taboo or prejudice towards milk consumption in this area like other parts of the country.

Even though dairy production is a source of nutritious food, income and job opportunities to the dairy producers; there is low production and productivity due to poor management practices such as feed and feeding system [6]. From the researchers point of view, the existing dairy cattle husbandry practices and coping strategies against feed scarcity during seasons of the year is need to be considered Amsalu [7] and and Belay Duguma and Geert [8]. During the long period of dry season dairy producers should be practiced coping strategies against feed scarcity through reducing herd size and conserve forage [9]. In fact Buno Bedele zone is not outside this circumstance. Moreover, these is no systematic research and development activities undertaken in the areas either by national government, regional or nongovernment organization to know the current status of dairy husbandry practices, nutritive value of major dairy feeds and coping strategies against feed scarcity during dry period. Therefore, in order to implement dairy sector development strategies in the area, it is essential to know details the overall dairy husbandry practices and investigation of coping strategies against feeds scarcity. Thus the current study was aimed with studying dairy husbandry practices and coping strategies against feed scarcity in the study area.

\section{Material and Methods}

\subsection{Description of Study Area}

The study was conducted in selected districts (Bedele, Didessa Dabo and Gechi districts) of Buno Bedele Zone. The zone was located at a distance of $481 \mathrm{~km}$ to south western of Addis Ababa, the capital city of Ethiopia. Currently, zone covers 1,633,156.56 hectares of land and contains 10 districts. Astronomically it is located at latitude and longitude lies between $8^{\circ} 27^{\prime}-8^{\circ} 45^{\prime} \mathrm{N}$ and $36^{\circ} 21^{\prime}-36^{\circ} 35^{\prime} \mathrm{E}$, respectively. The agro-ecological setting of the zone comprised of $10 \%$ high land, $67 \%$ mid land and $23 \%$ low land. The altitude of the zone ranges from 500-2,575 meter above sea level. Annual precipitation ranges from 1500$2200 \mathrm{~mm}$ with 6 to 9 months of rain fall Buno Bedele Agricultural Office [10]. The livestock potential of the zone is 437,688 of cattle, 117,052 of sheep, 94,377 of goats, 11,836 of horses, 568 of mules, 25,465 of donkeys, 250,379 of poultry and 100,662 of Beehives CSA [1].

\subsection{Sampling Procedure and Sample Size}

With the consultation of the Zone Livestock Resources and Fishery Development Office, four districts (Bedele, Didessa,
Dabo and Gechi) were purposively selected based on their potential in livestock population, particularly dairy cows. Then 3 kebeles from each district, a total of 12 kebeles having potential for dairy production were purposively selected. By using simple random sampling technique, a total of 384 household respondents were selected from the targeted kebeles. The total number of households included in the study was determined according to the formula given by Cochran (1977).

$$
\mathrm{n}=\frac{\mathrm{z}^{2}(\mathrm{p})(\mathrm{q})}{\mathrm{d}^{2}}=\frac{(1.96)^{2}(0.5)(0.5)}{(0.05)^{2}}=384
$$

Where: $\mathrm{n}=$ the sample size,

$\mathrm{z}^{2}=$ value for selected alpha level of 0.025 in each tail 1.96

(p) $(q)=$ the probability estimate value at 0.5 or (maximum possible proportion $(0.5)$

*1-maximum possible proportion $(0.5)$ produces maximum possible sample size),

$\mathrm{d}=$ acceptable margin of error for proportion being estimated $=0.05$

\subsection{Sources and Methods of Data Collection}

The required data according to the objectives of the study were collected by using primary and secondary data sources. Pre-tested semi-structured questionnaire and field observation were used to collect the primary data. To strengthen the survey data, focus group discussions were held with individuals who have knowledge and experience on dairy production. In addition, key informant interviews were made with Districts' Livestock and Fishery Resource Development Office experts and Development Agents (DAs). Then, secondary data were collected from zonal and districts agricultural offices, published journal articles, reports and other relevant documents.

\subsection{Methods of Data Analysis}

All the collected data were coded and entered into the computer Excel software. The Statistical Package for Social Sciences (SPSS) software (version 23.0) computer programs was used for data analysis using descriptive statistics (means, frequencies and percentages). Wherever ANOVA test was employed, the following two factorial ANOVA model was used.

$$
\mathrm{Y}_{\mathrm{ijk}}=\mu+\alpha_{\mathrm{i}}+\beta_{\mathrm{ij}}+\mathrm{e}_{\mathrm{ijk}}
$$

Where: $\mathrm{Y}_{\mathrm{ijk}}=$ production parameter

$\mu=$ Overall mean

$\alpha_{i}=$ the effect of $i^{\text {th }}$ districts $(i=1-3)$

$\beta_{\mathrm{ij}}=$ the effect of $\mathrm{j}^{\text {th }}$ nutritive feed of dairy cattle at dry and wet seasons $(j=1-2)$

$\mathrm{e}_{\mathrm{ijk}}=$ random error

\section{Results and Discussion}

\subsection{Characterization of Dairy Production}

In the study area, based on integrated with other 
agricultural practices, proximity to the urban center and market-oriented, dairy cattle production systems were characterized into mixed-crop dairy production (78.5\%), urban and peri-urban dairy production system (13\%) and other $(8.5 \%)$. Majority of the respondents were practicing mixed-crop dairy production due to the fact that livestock and crops are maintained as complementary enterprises. Because the livestock producers were depend on both crop and animal production for their livelihood improvement. This result was supported by the study of Amanuel et al. [11].

\subsection{Dairy Cattle Management}

\subsubsection{Major Source of Dairy Cattle Feed and Feeding}

The major feed resources in the study area were depicted in Table 1. In the present study, different feed resources were identified and categorized into: private natural pasture, communal pastures grazing, hay, green feeds (fresh or succulent grasses and legumes), crop residue, road and river side, aftermath grazing and also non-conventional feed were identified. The finding of the present study with regard to identified feed resources was in agreement with previous work of Sintayehu et al. [12] who reported natural pasture, hay, crop residue and non-conventional feeds were the most important feed resources used by urban dairy producers in different parts of Ethiopia.

Of the total respondents, majority $(42.9 \%)$ of them used communal natural pasture as the main feed source, especially during the wet seasons. Road and river side and aftermath grazing $(15.6 \%)$ used as feed resource of dairy cattle in the study area. As shown in table 1 , the feeding practices of dairy cows in the study area were $(90.1 \%)$ mixed with other livestock followed by $(9.6 \%)$ separately and $(0.3)$ tethering. As the result of field observation, during feeding the dairy cows were competing with other livestock, this might be due to lack of awareness or shortage of feed stuffs. This finding was in line with the result of Amanuel et al. [11].

Table 1. Major source of feed, feeding practice in the study areas.

\begin{tabular}{|c|c|c|c|c|c|}
\hline \multirow{2}{*}{ Variables } & \multicolumn{4}{|l|}{ Study District } & \multirow{2}{*}{ Total N(\%) } \\
\hline & Bedele N(\%) & Dabo Hana N(\%) & Didessa N(\%) & Gechi N(\%) & \\
\hline \multicolumn{6}{|l|}{ Major sources of feed for dairy cattle } \\
\hline Private pasture (hay) & $27(28.1)$ & $23(23.96)$ & $13(13.54)$ & $58(60.4)$ & $121(31.5)$ \\
\hline Communal pasture & $38(39.6)$ & $51(53.1)$ & $39(40.6)$ & $35(36.4)$ & $163(42.9)$ \\
\hline Crop residue/hay & $14(14.6)$ & $7(7.3)$ & $19(19.8)$ & 0 & $40(10.4)$ \\
\hline Road and river side and aftermath grazing & $17(17.7)$ & $15(15.6)$ & $25(20.4)$ & $3(3.1)$ & $60(15.6)$ \\
\hline Total & $96(100)$ & $96(100)$ & $96(100)$ & $96(100)$ & $384(100)$ \\
\hline Separately & $9(9.4)$ & $12(12.5)$ & $9(9.4)$ & $7(7.3)$ & $37(9.6)$ \\
\hline mixed with other livestock & $87(90.6)$ & $83(86.4)$ & $87(90.6)$ & $89(92.7)$ & $346(90.1)$ \\
\hline tethering & 0 & $1(1.04)$ & 0 & 0 & $1(0.3)$ \\
\hline
\end{tabular}

\subsubsection{Feeding System}

Table 2 represented the different feeding systems practiced by dairy farmers in the study area. The result of study emphasized that respondents practiced different feeding practices based on land availability and season of the year. Free grazing remains the major system of feeding (72.12) practiced as compared to tethering during wet grazing $(27.8 \%)$ systems. All the respondents indicated that feed shortage is the main challenging of dairy cattle production in the study area. This might be due to increased human population (52.6\%); expanding crop production $(22.1 \%)$ and decline of grazing land (15.1\%). This result was agreed with the report Sintayehu et al. [12].

Table 2. Feeding system, feed availability, in the study area.

\begin{tabular}{llllll}
\hline \multirow{2}{*}{ Variables } & Study District & & & \multicolumn{1}{c}{$\begin{array}{l}\text { Overall Total } \\
\text { N(\%) }\end{array}$} \\
\cline { 2 - 4 } & Bedele N(\%) & Dabo Hana N(\%) & Dedesa N(\%) & Gechi N(\%) & \\
Which type of feeding system you practice? & $74(77.08)$ & $83(86.46)$ & $90(93.75)$ & $30(31.25)$ & $277(72.12)$ \\
$\begin{array}{l}\text { Free grazing during dry period } \\
\text { Tethering during wet season }\end{array}$ & $22(22.92)$ & $13(13.5)$ & $6(6.25)$ & $66(68.75)$ & $107(27.8)$ \\
$\begin{array}{l}\text { Is there feed shortage in your area? } \\
\text { Yes }\end{array}$ & $96(100)$ & $96(100)$ & $96(100)$ & $96(100)$ & $384(100)$ \\
No & 0 & 0 & 0 & 0 & 0 \\
If yes, due to what? & $21(21.9)$ & $20(20.83)$ & $23(23.96)$ & $21(21.9)$ & $85(22.1)$ \\
Expanding crop production & $15(15.62)$ & $3(3.1)$ & 0 & $40(41.7)$ & $58(15.1)$ \\
$\begin{array}{l}\text { Decline in productivity of grazining land } \\
\text { increased animal population }\end{array}$ & 0 & $3(3.1)$ & 0 & 0 & $3(0.8)$ \\
increased human population & $55(57.29)$ & $55(57.3)$ & $73(76.04)$ & $19(19.8)$ & $202(52.6)$ \\
Increasing crop production and human population & $5(5.21)$ & $15(15.62)$ & 0 & $16(16.7)$ & $36(9.4)$ \\
\hline
\end{tabular}

\subsubsection{Supplementary Feeding}

Practices of supplementary feeding were presented in table 3. About $94.5 \%$ of the interviewed farmers were supplementing their dairy cows. About $27.9 \%$ of the respondent used house west, Atela and common salt as a major supplementary feed, followed by grain leftover mix $(27.6 \%)$, mill by products $(20.3 \%)$, grain leftover and atela and common salt $(19.01 \%)$. Since shortage of feeds is highly 
occurred during dry season of the year, majority $(83.9 \%)$ of the households experienced feeding of supplementary feeds for their animals (Table 3). This result was also in agreement with the study of Sintayehu et al. [12].

Table 3. Supplementary feeds, practice in the study areas.

\begin{tabular}{|c|c|c|c|c|c|}
\hline \multirow{2}{*}{ Variables } & \multicolumn{4}{|l|}{ Study District } & \multirow{2}{*}{$\begin{array}{l}\text { Overall } \\
\text { Total N(\%) }\end{array}$} \\
\hline & Bedele N(\%) & Dabo Hana N(\%) & Dedesa N(\%) & Gechi N(\%) & \\
\hline Do you practice supplementary feeding? & $92(958)$ & $96(100)$ & $96(100)$ & $70(823)$ & $363(045)$ \\
\hline $\begin{array}{l}\text { If yes, w/c type of supplementary feeds? } \\
\text { grain leftover }\end{array}$ & $29(30.2)$ & $12(12.5)$ & $12(12.5)$ & $53(55.21)$ & $106(27.6)$ \\
\hline House west, Atela and common salt & $26(27.1)$ & $38(39.6)$ & $36(37.5)$ & $7(7.3)$ & $107(27.9)$ \\
\hline Grain leftover and atela and common salt & $18(18.75)$ & $24(25)$ & $23(23.9)$ & $8(8.3)$ & $73(19.01)$ \\
\hline $\begin{array}{l}\text { other } \\
\text { In w/c season you supplement your dairy cow? }\end{array}$ & $4(4.2)$ & 0 & 0 & $16(16.7)$ & $20(5.2)$ \\
\hline Dry season & $84(87.5)$ & $85(88.5)$ & $96(100)$ & $57(59.4)$ & $322(83.8)$ \\
\hline Wet season & 0 & 0 & 0 & $1(1.04)$ & $1(0.3)$ \\
\hline Both dry and wet season & $9(9.4)$ & $11(11.45)$ & 0 & $23(23.9)$ & $43(11.2)$ \\
\hline others & $3(3.1)$ & 0 & 0 & $15(15.6)$ & $18(4.7)$ \\
\hline
\end{tabular}

\subsubsection{Drinking Water for Dairy Cattle}

River, pip water and deep water were the major drinking water in the study area accounted for $72.13 \%, 22.1 \%$ and $5.73 \%$, respectively (Table 4). Of the total respondent, $73.9 \%$ were provided water for their animals twice per day during dry seasons of the year. As reported by Adebabay [13] in Alefa district of North Gondar zone, $66.7 \%$ of the respondents was watered their dairy cattle twice per day.

\subsubsection{Housing of Dairy Cattle}

The current result indicated that $72.65 \%$ of the respondents housed their dairy cows in open kraal followed by adjoin house $(22.92 \%)$. About $72.65 \%$ of the dairy producers were not used roof for house construction and only $15.1 \%$ were made house from grass (Table 4). This result was supported by the study of both Adebabay [13] and Tegegne et al. [14].

Table 4. Source of drinking water, frequency of watering, housing of dairy cattle in the study areas.

\begin{tabular}{|c|c|c|c|c|c|}
\hline \multirow{2}{*}{ Variables } & \multicolumn{4}{|l|}{ Study District } & \multirow{2}{*}{$\begin{array}{l}\text { Overall Total } \\
\mathbf{N}(\%)\end{array}$} \\
\hline & Bedele N(\%) & Dabo Hana N(\%) & Dedesa N(\%) & Gechi N(\%) & \\
\hline \multicolumn{6}{|l|}{ Source of drinking water for dairy cattle } \\
\hline River & $63(65.6)$ & $72(75)$ & $50(52.1)$ & $92(95.8)$ & $277(72.13)$ \\
\hline Piper water & $27(28.1)$ & $18(18.75)$ & 40 (41.7) & 0 & $85(22.1)$ \\
\hline Deep water & $6(6.25)$ & $6(6.2)$ & $6(6.2)$ & $4(4.2)$ & $22(5.73)$ \\
\hline Total & $96(100)$ & $96(100)$ & $96(100)$ & $96(100)$ & $384(100)$ \\
\hline \multicolumn{6}{|l|}{ Frequency of watering during dry season? } \\
\hline once a day & $25(26.04)$ & $13(13.5)$ & $16(16.7)$ & $38(39.6)$ & $92(23.9)$ \\
\hline Twice a day & $70(72.92)$ & $82(85.42)$ & $80(83.3)$ & $52(54.2)$ & $284(73.9)$ \\
\hline Every other day & $1(1.04)$ & $1(1.04)$ & 0 & $6(6.25)$ & $8(2.08)$ \\
\hline \multicolumn{6}{|l|}{ Frequency of watering during wet season? } \\
\hline twice a day & $24(25)$ & $19(19.8)$ & $19(19.8)$ & $38(39.6)$ & $100(26.04)$ \\
\hline \multicolumn{6}{|l|}{ Where you confine dairy cattle? } \\
\hline Adjoin house & $15(15.6)$ & $38(39.6)$ & $20(20.8)$ & $15(15.6)$ & $88(22.92)$ \\
\hline separately constructed house & $1(1.04)$ & 0 & 0 & $3(3.1)$ & $4(1.04)$ \\
\hline Open Kraals & $76(79.2)$ & $54(56.25)$ & $76(79.2)$ & $73(76.04)$ & $279(72.65)$ \\
\hline \multicolumn{6}{|l|}{ Materials used for house roof construction } \\
\hline grass & $15(15.6)$ & $14(14.6)$ & $16(16.7)$ & $13(13.54)$ & $58(15.1)$ \\
\hline stone/brick & $2(2.08)$ & 0 & 0 & $3(3.1)$ & $5(1.3)$ \\
\hline None & $78(81.25)$ & $59(61.45)$ & $80(83.3)$ & $70(72.92)$ & $287(74.74)$ \\
\hline \multicolumn{6}{|l|}{ Materials used for house wall construction } \\
\hline wood and mud & $15(15.6)$ & $38(9.9)$ & $20(20.8)$ & $11(11.46)$ & $84(21.9)$ \\
\hline concrete & 0 & $4(4.2)$ & 0 & $8(8.3)$ & $12(3.1)$ \\
\hline wood only & $79(82.3)$ & $54(56.25)$ & $76(79.2)$ & $74(77.08)$ & $283(73.7)$ \\
\hline \multicolumn{6}{|l|}{ Materials used for house floor construction } \\
\hline earth/mud & $95(98.9)$ & $93(96.9)$ & $96(100)$ & $86(89.6)$ & $370(96.35)$ \\
\hline Others & 0 & 0 & 0 & $1(1.04)$ & $1(0.3)$ \\
\hline
\end{tabular}




\subsubsection{Common Disease of Dairy Cattle in the Study Areas}

In the study area, Trypanosomiasis (23.44\%), Mastitis (19.8\%) and Foot and mouth disease (FMD (17.7\%) were among the frequently occurring dairy cow diseases in the study area (Table 5). of the total about $61.72 \%$ of the dairy producers treat their sick animals and by taking to veterinary clinic and about $38.28 \%$ use traditional medicine.

Table 5. Common disease of dairy cattle in the study areas.

\begin{tabular}{|c|c|c|c|c|c|c|}
\hline \multirow{2}{*}{ Variables } & \multicolumn{4}{|l|}{ Study Districts } & \multirow{2}{*}{$\begin{array}{l}\text { Total Overall } \\
\mathbf{N}(\%)\end{array}$} & \multirow{2}{*}{ Rank } \\
\hline & Bedele N(\%) & Dabo Hana N(\%) & Dedesa N(\%) & Gechi N(\%) & & \\
\hline \multicolumn{7}{|c|}{ Common disease of the dairy cattle } \\
\hline Black leg & $18(18.9 \%)$ & $18(18.9 \%)$ & $25(26.04 \%)$ & $3(3.12 \%)$ & $64(16.7 \%)$ & $4^{\text {th }}$ \\
\hline FMD & $13(13.5 \%)$ & $16(16.7 \%)$ & $10(10.42 \%)$ & $32(33.3 \%)$ & $68(17.7 \%)$ & $3^{\mathrm{rd}}$ \\
\hline Mastitis & $19(19.8 \%)$ & $27(28.12 \%)$ & $21(21.9 \%)$ & $11(11.46 \%)$ & $76(19.8 \%)$ & $2^{\text {nd }}$ \\
\hline Pasteurolosis & $11(11.46 \%)$ & $13(13.54 \%)$ & $18(18.75 \%)$ & 0 & $37(9.60 \%)$ & $5^{\text {th }}$ \\
\hline Skin Disease & $11(11.46 \%)$ & $8(8.3 \%)$ & $12(12.5 \%)$ & $4(4.2 \%)$ & $35(9.11 \%)$ & $6^{\text {th }}$ \\
\hline
\end{tabular}

\subsection{Coping Strategies Against Feed Scarcity}

In the study area as the result of the study indicated change of feed resources based on availability and cost, rent land and grow fodder and reducing herd size which was accounted by $26.3 \%, 23.7 \%$ and $21.4 \%$, respectively (Table 6 ) were among the coping strategies that the dairy farmers applied in order to overcome the problem of feed scarcity. The present result was in line with the report of Leng [15] who reported changing feed resources based on availability is the first strategy used for cattle and pig farmers overwhelm the feed shortage.

Table 6. Copying strategies against feed scarcity.

\begin{tabular}{|c|c|c|c|c|c|}
\hline \multirow{2}{*}{ Parameter } & \multicolumn{4}{|l|}{ Districts } & \multirow{2}{*}{ Total N (\%) } \\
\hline & Bedele N (\%) & Dabo hana N (\%) & Didessa N (\%) & Gechi N (\%) & \\
\hline Using conserved forage (hay, silage) & $6(1.6)$ & $3(0.8)$ & $6(1.6)$ & $2(0.5)$ & $17(4.4)$ \\
\hline Change feed recourse based on availability and cost & $33(8.6)$ & $20(5.2)$ & $46(12.0)$ & $2(0.5)$ & $101(26.3)$ \\
\hline Reducing herd size & $15(3.9)$ & $15(3.9)$ & $6(1.6)$ & $46(12.0)$ & $82(21.4)$ \\
\hline Using non-conventional feed & $11(2.9)$ & $18(4.7)$ & $15(3.9)$ & $5(1.3)$ & $49(12.8)$ \\
\hline Rent land and grow fodder & $20(5.2)$ & $35(9.1)$ & $19(4.9)$ & $17(4.4)$ & $91(23.7)$ \\
\hline Resort free roaming & $11(2.9)$ & $5(1.3)$ & $4(1.0)$ & $24(6.2)$ & $44(11.5)$ \\
\hline
\end{tabular}

\section{Conclusions}

The result of the present study would seem to suggest that the production and productive performance of dairy cattle is governed by multiple factors. The major factor affecting the production and productivity of dairy cattle in the study area were poor husbandry practices (housing, feeding, breeding, health care) and shortage of feed scarcity in dry season and absence of preparatory for overcoming the feed shortage. Therefore, the dairy farmers in the study area should supplement adequate supplementary feeds and coping strategy against feed scarcity need to be permanent to increase dairy productivity.

\section{References}

[1] CSA (Central Statistics Authority). Agricultural Sample Survey, Volume II: Report on Livestock and livestock characteristics, Statistical Bulletin 587, Addis Ababa, Ethiopia, (2020) 1-182.

[2] Dayanandan, R. Production and marketing efficiency of dairy farms in highland of Ethiopia- an economic analysis. International Journal of Enterprise Computing and Business Systems, 2020. 1 (2): 1-34.
[3] Lemma, T., Puskur, R., Hoekstra, D. and Tegegne, A. Commercializing dairy and forage systems in Ethiopia: An innovation systems perspective. Working Paper 17. ILRI (International Livestock Research Institute), Nairobi, Kenya (2010) 57 pp.

[4] CSA (Central Statistical Authority). Federal Democratic Republic Of Ethiopia, Central Statics Agency, Agricultural Sample Survey: Report Of Livestock And Livestock Characteristics. Addis Ababa, Ethiopia (2017/18).

[5] Stypinski P. The Effect of Grassland-based Forages on Milk Quality and Quantity. Agronomy Research (Special Issue II) (2011) 479-488, 2011.

[6] Behnke, R., and Metaferia, F. The contribution of livestock to the Ethiopian economy - part II. IGAD LPI (Livestock Policy Initiative of the Intergovernmental Authority on Development) Working Paper 02-11. Addis Ababa, Ethiopia: IGAD Livestock Policy (2011).

[7] Amsalu Sisay. Herbaceous species composition, dry matter and condition of the major grazing areas in the middle rift valley, Ethiopia. MSc. Thesis, School of Graduate Studies, Alemaya University, Dire Dewa, Ethiopia (2015).

[8] Belay Duguma and Geert Paul Jules Janssens. Assessment of feed resources, feeding practices and coping strategies to feed scarcity by smallholder urban dairy producers in Jimma town, Ethiopia. Springer Plus (2016) 5: 717. DOI 10.1186/s40064016-2417-9. 
[9] Constantine Bakyusa K., Justine Nambi-Kasozia, Richard Lumua, Felix Bareebaa, Magdalena Prestob, Emma Ivarssonb, Jan Erik Lindbergb. Strategies for coping with feed scarcity among urban and peri-urban livestock farmers in Kampala, Uganda. Journal of Agriculture and Rural Development in the Tropics and Subtropics Vol. 113 No. 2 (2012) 165-174.

[10] Buno Bedele Agricultural Office (BBAO). Annual Report, Bedele, Ethiopia (2018).

[11] Amanuel B., Wahid M. A., Lemma F. and Ulfina G. Study on Dairy Production System and Its Constraints in Gimbi District, West Wollega Zone, Oromia, Ethiopia, Global Veterinaria, 20 (5): 215-224, 2018.

[12] Sintayehu, Y., Fekadu, B., Azage, T. and Berhanu, G. Dairy production, processing and marketing systems of Shashemene-Dilla area, South Ethiopia (2008).
[13] Adebabay, K. 'Characterization of Milk production Systems, Marketing and On-farm Evaluation of the Effect of Feed Supplementation on Milk Yield and Milk Composition of Cows at Bure district, Ethiopia.' MSc Thesis, Bahir Dar University, Ethiopia (2009).

[14] Tegegne, N., Dinku, G. and Moahmmed, B. Assessment of potential of natural pasture and other feed resources in sweet potato production system of Shebedino district, Sidama zone, SNNPR, Ethiopia. International Journal of Livestock Production, 6 (8) (2015.) 91-98.

[15] Leng, R.. Feeding strategies for improving milk production. 207-224. In: Smallholder Livestock Development. Proceeding of the 12th Annual Conference of Ethiopian Society (1999). 